\title{
State and Revolution: Reflections from South African Institutions of Higher Learning
}

\author{
Mavhungu Elias Musitha \\ Senior Manager, Department of Information Services \\ Limpopo Tourism Agency, 9 Waterbessie, Street, Makhado, 0920 \\ South Africa
}

Email: mavhungu.musitha@gmail.com

Received: November 06, 2016 Accepted: December 02, 2016 Published: December 11, 2016

doi:10.5296/jpag.v6i4.10312 URL: http://dx.doi.org/10.5296/jpag.v6i4.10312

\begin{abstract}
Democratic states should use democratic principles namely engagement, negotiation, discussion, persuasion and participation to resolve challenges in societies. This is in contrast to colonial and apartheid states which used police, army, imprisonment, exile or banishment from the country against blacks who demanded democratic rights. This study investigates whether democratic South Africa embraces democratic principles highlighted above to deal with its domestic problems or is merely an extension of colonial and apartheid states in addressing challenges it faces. The study makes use of literature to answer the question. This is a qualitative study. The study found that democratic South Africa uses the same undemocratic instruments as evidenced by its handling of the \#FeesMustFall campaign. \#FeesMustFall leaders and students are being shot at, arrested, and imprisoned in the same jails built and used by the apartheid state, stun grenades are being thrown at them and tear gas sprayed at them. The conclusion of this study is that by implementing similar instruments of maintaining security there is no difference between the means used by oppressive colonial and apartheid governments of the past and those used by democratic SA today.
\end{abstract}

Keywords: State, Revolution, \#FeesMustFall, Institutions of higher learning, colonial police and prisons. 


\section{Introduction}

Colonial and democratic states have emerged from one another when the latter overthrew the former through revolutions to establish democratic society. The former, representing colonialism and apartheid, relied on undemocratic instruments such as the police, army and prisons to maintain law and order which was aimed at Africans who were labeled "terrorists" and "rebels" for defending their countries against encroachments by whites who arrived in Africa from Europe following the Berlin Conference which carved up Africa into various territories and allocated them to European countries, thus beginning the process of colonialism and imperialism in Africa. But in South Africa, the arrival of whites began in the late 1400s when the Portuguese were followed by the Dutch who arrived in 1652. The police, army and prisons were used to dispossess land from Africans who were thrown into prisons, forced into exile, and hanged by both colonial and apartheid regimes. Blacks, and Africans in particular, where excluded from participating in colonial and apartheid governments and as a result were disenfranchised. From 1958 to 1994 one African country after another mounted revolutions which destroyed both colonial and apartheid regimes and ushered in democratic governments. According to Schwarzmantel (2010) the aim of democracy is to ensure that violence is prevented and democratic participation by civil society promoted to resolve problems. Yet democratic states also resort to using violence as and when they are under threat (Schwarzmantel (2010) particularly when there is a reluctance to participate in engagements as a strategy to render negotiations illegitimate (Musitha, 2016, 1). This, therefore, renders governance both a theoretical and practical tool as a response to crises of governability and legitimacy (Goetz, 2008). In a case like South Africa the matter that can force the state to resort to violence may be motivated by social and economic ills such as poverty. Poverty is caused by limited access to basic services, poor housing, limited employment opportunities and inadequate infrastructure, which were the deliberate policies of apartheid. The South African government implemented aggressive neoliberal strategies of privatization, liberalization and deficit reduction through GEAR to stimulate the economy and create jobs - all of which backfired (Cheru, 2010). In South Africa in 2015 and 2016, students at higher learning institutions across the country felt that the new government that had come into office after the fall of apartheid was not doing enough in decolonize the apartheid era universities which were established along ethnic and racial lines when the National party introduced apartheid in 1948. Statues of former white leaders towered majestically above all the university campuses and blacks felt intimidated by them and revolted against both the state and the universities. But what is the state and why does it occupy such a crucial role in society? The term "state" refers to a set of different, but interrelated and often overlapping, theories about a certain range of political phenomena (Wikipaedia, 2016). According to Fanon $(1965,29)$, the colonial system's ruling class was characterised by barracks, army, policemen and police stations. On the other hand, democratic states are expected to use democratic principles such as engagement, negotiation, discussion, persuasion and participation to resolve challenges faced by societies. This study investigates whether South Africa as a democratic state embraces democratic principles in dealing with \#FeesMustFall campaign of students in higher learning institutions or is just an extension of the defunct colonial and apartheid states. 


\section{Literature Review}

There have been many different and contrasting views about how to define the state among academics, political scientists and philosophers. As a result the term "state" refers to a set of different, but interrelated and often overlapping, theories about a certain range of political phenomena (Wikipedia, 2016). Marxists define state as the product of irreconcilable class antagonisms. In the course of these antagonisms, revolutionary thinkers and leaders of oppressed classes have developed theories in order to justify their struggle for emancipation. As a result revolutionaries faced terrible persecution and even death at the hands of the ruling class (Lenin, 1917, 6). Revolutionaries are only recognised by their persecutors once they are dead as we saw with the assassination of Peter Tosh in 1997 in Jamaica. According to Engels (1972), "the state is, therefore, by no means a power forced on society from without; just as little is it 'the reality of the ethical idea', 'the image and reality of reason', as Hegel maintains. Rather, it is a product of society at a certain stage of development; it is the admission that this society has become entangled in an insoluble contradiction with itself, that it has split into irreconcilable antagonisms which it is powerless to dispel. But in order that these antagonisms be reconciled, these classes with conflicting economic interests, might not consume themselves and society in fruitless struggle, it became necessary to have a power, seemingly standing above society, that would alleviate the conflict and keep it within the bounds of 'order'; and this power, arising out of society but placing itself above it, and alienating itself more and more from it, is the state" (Lenin, 1917, 6). But Marx sees the state as an organ of class rule, an organ for the oppression of one class by another; it is the creation of "order", which legalizes and perpetuates this oppression by moderating the conflict between classes. Weber's definition referring to the state as a human community that successfully claims the monopoly of the legitimate use of physical force within a given territory (Weber, 1946) is widely used in contemporary political science. According to Fanon $(1965,29)$, the colonial system's ruling class is characterised by barracks and police stations. Colonial authorities use policeman and soldiers who are the officials, appointed go-betweens and spokesmen of the settler and his rule of oppression. But the oppressive state needs to be transformed through the process of decolonisation in order to create new men. The ANC (1997) argued that revolutionaries do not rest after the overthrow of dictatorial regimes but go on to advocate that the state machinery should be changed to serve the people through social transformation. The civil service, the judiciary, the army, the police and the intelligence structures which were established to attain the opposite of what the people intended to achieve, should be made to serve the purpose of social transformation. The state should be a critical factor in transformation (ANC, 1997, 34). Its role should be the organ through which any society mediates its moral values to establish an acceptable social morality which members of the society collectively regard as desirable (ANC, 1998, 6). According to Frederick Engels, armed men, prisons and other institutions of coercion were not part of the gentile society. He further refers to the state as power which has arisen from within society and maintains this power through use of an army and police which are the chief instruments of state power, thereby alienating itself more and more from the society it aims to defend. Engels further sees the state as an instrument for exploitation of the oppressed class through the special public power and the right to levy taxes through "the officials who now stand, as 
organs of society, above society". But Engels brings to the public domain the issue of the origin of the state which according to him was not there and to quote his words:

"The state, then, has not existed from all eternity. There have been societies that did without it".

Revolutions are aimed at radically changing states by unconstitutional means. But what is a revolution? Revolution includes attempts to transform political institutions and justifications for political authority in a society accompanied by formal and informal mass mobilisation and uninstitutionalized actions that undermine the authorities (Goldstone 2001). It is regarded as a fundamental change in political power or organizational structures that takes place in a relatively short period of time when the population rises up in revolt against the ruling authorities (Wikipedia, 2016). Neitzel (N.D) describes revolution as radical, transformative change with many generic uses that describe phenomena from the industrial to the sexual. As a historical process it refers to a movement, often violent, to overthrow an old regime and effect complete change in the fundamental institutions of society. However, Aristotle describes two forms of revolutions, namely, a complete change from one constitution to another and one that seeks modification of an existing constitution (cited in Wikipedia, 2016). Two major revolutions took place in South Africa and are briefly outlined below.

\subsection{First South African Student Revolution}

The 1976 student revolution was organized by the banned liberation movements who operated in exile using internal structures that used school learners to challenge the proposed introduction of the Afrikaans language as a medium of instruction. Teachers, parents and citizens joined the uprising which was on the scale of a revolution (Iwase, 2014, 1). The Afrikaans language was used as a pretext while the real issue was the overthrow of the apartheid state (Hyslop in Cobbett \& Cohen, 1988, 186-187). It was aimed at radical change by liberation movements led by the African National Congress in exile in order to establish a democratic government elected by a black majority population. After killing some students, forcing others into exile or imprisoning them, the international community was forced to condemn the brutality of the apartheid police machinery against unarmed students (Iwase, 2014, 1).

\subsection{5 / 2016 Second South African Student Revolution}

The Second Revolution is once again led by students but this time it is the students of institutions of higher learning. While the 2015 protests were aimed at the removal of apartheid symbols such as statues that emphasised the role of colonial and apartheid heroes at universities, the main issue was the \#FeesMustFall demand. Students demanded that there should be no increase in tuition fees for the year 2016. They invaded Parliament and the Union Building (seat of government) and encountered violence and police brutality. In 2016, the revolution intensified the demand for either no fee increase or free university education for all. But this revolution is different to the one in 1976 because, as Aristotle indicated, it is not aimed at a complete change from one constitution to another but the modification of an existing constitution. This is evident in the manner in which students are reminding the ruling 
class that it should implement free education according to the Constitution of the Republic of South Africa 1996 and the Freedom Charter of 1956 as well as the Polokwane Resolutions (2007) and Mangaung Resolutions (2012).

\section{Statement of the Problem}

The Constitution of the Republic of South Africa, 1996 was introduced into the new country to reverse political, social and economic inequalities imposed on the country by the apartheid state from 1948 when apartheid was legalized. The Apartheid state had established separate universities along ethnic and racial lines. Black universities were located in rural and reserve areas but were put under the tutelage of white administrators. The university education system was aimed at promoting the superiority of apartheid over black history. Because of inequality and poverty, few blacks were able to proceed to universities compared to their white counterparts. The apartheid state used coercive measures, namely the army, police and prisons to silence all those who advocated democratic principles for the country. This study highlights the dangers of the failure of a democratically elected state to implement the articles of the constitution. The study also investigates the continuous legalization of both colonial and apartheid measures to control the people.

\section{University Protesters Storm the National Assembly (Parliament)}

In order to draw attention to their grievances, university students stormed the parliamentary sitting on 21 October 2015. Nearly all the security personnel and politicians alike were caught unawares on the day by the unprecedented event which attracted global media attention. Students blamed high levels of inequality that existed between the rich and the poor in South Africa (Mbele \& Davids 2015). The state responded by unleashing the security forces such as the National Joint Operational and Intelligence Structure (NATJOINTS) comprising the South African Police Service and various Government departments as well as the Provincial JOINTS to ensure that a multi-disciplinary approach was followed with regards to protest actions taking place throughout the country. This was to ensure that the Constitutional Rights of all are protected. Protests were largely peaceful but police pushed back the angry crowds outside parliament and also used stun grenades to disperse them. The students who had been arrested could face charges of trespassing and public violence. The \#FeesMustFall movement also received a global boost when in central London hundreds of people gathered in front of the South African High Commission in solidarity with the campaign before marching.

\section{1. \#RhodesMustFall}

Cecil John Rhodes was Prime Minister and President of the Cape Colony. However, he was British and wanted to extend the British Empire on the African continent. The following statement he delivered in 1887 in Cape Town showed him to be a racist who hated Black people:' the native is to be treated as a child and denied the franchise. We must adopt a system of despotism in our relations with the barbarians of South Africa' (Pambazuka News). In his quest to extend the British Empire, he dreamed of an empire stretching from the Cape to Cairo. In putting this vision into practice, he orchestrated violent land appropriation 
campaigns in Nyasaland, Northern Rhodesia and Southern Rhodesia which have since been renamed Malawi, Zambia and Zimbabwe respectively. Those land grabs are at the root of liberation struggles in southern Africa (South African History). It is also alleged that his network of stolen wealth was used to establish the universities of Rhodes which was established through the donation granted by Rhodes Trust, Cape Town which was built on the land donated by Rhodes, Witwatersrand and Pretoria (Pambazuka News). The legacy of Rhodes is associated with racism, plunder, white supremacy, colonialism, dispossession and oppression of the black population (News 24). In 2015 University students in South Africa embarked on the \#RhodesMustFall campaign at the universities of Cape Town and Rhodes campuses. The statues of Rhodes were reminders of racism which South African students faced every day at the university campus and protests led to their removal at Rhodes and Cape Town universities as a form of cleansing from the past colonial era (Harvey and Fakir, 2016, 26). Evans (2015) reported on News 24 that President Mugabe of Zimbabwe had made a joke about the protest action against the statue of Rhodes by saying that he was surprised because in Zimbabwe they were "looking after his corpse while South Africa had a statue".

\section{2. \#FeesMustFall Student Campaign}

The \#FeesMustFall campaign began in 2015 when university students demanded no increase in fees in 2016 (Ndebele, 2016). The same newspaper predicted that the re-opening of tertiary institutions could face a rocky start. Njabulo Ndebele reminded the nation that two momentous campaigns defined the year 2015 since the passing of President Nelson Mandela and these campaigns were \#RhodesMustFall and \#FeesMustFall (Ndebele, 2016). The campaign was put on hold after a commission was put in place to investigate strategies for a new funding model. On $19^{\text {th }}$ September 2016, the department and the Council on Higher Education through the Minister of Higher Education announced that universities would individually decide on the percentage increase of fees capped at $8 \%$ for the academic year 2017 (Tau, 2016, 5). In 2016 universities did not increase fees following instructions from the President.

The students' demand in \#FeesMustFall is in line with what Sargent $(2009,77)$ calls demand for free education and equality of opportunity whereby no artificial barriers should keep anyone from achieving what they can through ability and hard work (Sargent, 2009, 77). In 2016 the President instructed the Ministers of Higher Education and the Treasury to identify alternative sources of funding to avoid fee increases for 2017 (Cele, 2016, 1). The President appears to be endorsing the call by the Progressive Youth Alliance (PYA) comprising the ANC Youth leagues, the Young Communist League, University and school student bodies, namely the Congress of South African Students (COSAS) and the South African Students Congress (SASCO) (Cele, 2016, 1). In 2016, the FeesMustFall campaign was extended to mean that university fees must fall to give way to free university education for all. The Fees Commission Chairperson, Judge Heber who was appointed by the President to investigate possibilities of funding university education has pointed out that 'free education was never free'. He further stated that there were very few countries in the world who could afford free education (Makhubu, et al., 2016). Buys $(2016,17)$ is of the view that students should convene a convention which would empower students to suggest the way forward to achieve 
their aims of free university education. Cele and Stone $(2016,2)$ quote one of the students' leaders, Mr. Mcebo Dlamini in his own words:

'We are determined and committed to achieve the cause of free, decolonized education for all'.

\subsection{Police Brutal Response}

\#FeesMustFall has created the space for the men in uniform to unleash brutality in this democratic state almost in the same way the apartheid state operated. Macupe $(2016,2)$ reported that police used stun grenades and rubber bullets to disperse protesting students. Heavily armed police blocked the marching students because "they did not have permission to do so". This was all done in the name of maintaining law and order just as the colonial and apartheid state did before both were defeated, setting in motion new independent states in Africa (Buys, 2016, 17). One of the students describing the actions of the police said that "we are living in a police state". On $3^{\text {rd }}$ October 2016, a member of the portfolio committee of higher education Sbongile Mchune called for the army to be deployed at universities after the Imbizo, convened to resolve the fees crisis, collapsed (SABC, SAFM Radio at $17 \mathrm{hr}$ news. An unarmed student was being brutally dragged away by heavily armed police during the protest action (Macupe, 2016, 2).

For 2016, the state plans to target the actual perpetrators of violence and not carry out random arrests because the latter creates confusion when evidence is not forthcoming (Cele \& Stone, 2016).

\section{Research Design and Methodology}

\subsection{Study Area}

This study is conducted in South Africa. South Africa received its first recorded whites in 1652 from Holland. The first white people to arrive in South Africa were led by Jan Van Riebeeck who landed at the Cape. In 1820 a group called Free Burgers also arrived from various European countries. Upon their arrival, like Jan van Riebeeck, they engaged in border wars against the native Blacks when they tried to take land and livestock from them. These wars persisted until the 1900s and came to an end in 1902 with the signing of the Peace of Vereeniging which ended the Anglo-Boer war. As a gesture of reconciliation the two white groups decided to form a Union government and both identified Blacks as their common problem. In 1913, the Native land Act was passed where Blacks were to be confined in reserves within their own motherland. The worst came in 1948 when the Nationalist party won a general election and immediately implemented its manifesto which was presented to voters as Apartheid or separate development. The Nationalist party began to implement apartheid and in 1953 the Bantu Education Act was passed and the process of establishing separate universities began. From that moment Blacks and whites began to attend separate schools and universities following the passing of the Extension of University Education Act. The establishment of separate universities was motivated by the political ideology of the apartheid government. These universities which were established to cater for black university students were administered by white Afrikaners who were appointed Rectors or Principals of 
these universities. Councils and Senates were also controlled by whites, particularly Afrikaners (Gwala in Cobbert \& Cohen (1988, 169). According to Musitha \& Tshibalo (2016, 9), six universities were designated to serve Blacks and particularly African students. Since 1994, universities have been forced to open their door to all but persisting racism still lingers on which frustrates black students and those who want to decolonize the education curriculum. In demanding a decolonized curriculum, they think that there is a particular body of knowledge that belongs to a particular civilization (Makhanya, 2016).

\subsection{Research Design}

Research design is defined as the blueprint for fulfilling research objectives and answering research questions. It is actually a master-plan that specifies methods and procedures for collecting and analyzing data. Its purpose is to ensure that the information collected is appropriate for solving a problem (Adams, 2007, 81). It is the road map that the researcher decides to follow in a research journey to find answers to research questions as validly, objectively, accurately and economically as possible. It is regarded as a procedural-cum-operational plan that puts in detail what and how different methods and procedures are applied during the research process (Kumar, 2014, 122). According to Creswell et al., $(2010,70)$ research design is a plan or a strategy which moves from the underlying philosophical assumption to specify the selection of respondents, the data gathering techniques to be utilized and data analysis. Two major designs, namely qualitative and quantitative are proposed by Creswell et al $(2010,70)$. This study therefore adopts a qualitative technique which relies on data in the form of words and seeking the meaning of human actions. (Schwardt, 2001) cited in Badenhorst (2008, 92). Researchers are interested in understanding and also engaging in an argument by applying evidence from data and literature about the phenomenon that is under study (Henning et al., 2004, 272).

\subsection{Data Collection Methods}

Data are defined as facts and figures collected for records or any statistical investigation. There are two main sources of data that are used for research purposes, namely primary and secondary Adams et al. (2007, 85). This study is based on secondary data defined by Crowther and Lancaster $(2009,89)$ as second hand since it is not new data. Of course its importance lies in providing a baseline before any data is collected for the first time. If secondary data answer the research question sufficiently there is no reason to go and collect new data. The data that are used for this study are obtainable mainly from newspapers such as City Press, Citizens, Pretoria News, Sunday Times, the Star, and Sowetan. Websites were also visited for more information. Books have also been consulted in order to provide the information to answer the research objectives.

\section{Conclusion}

The literature review for this study has revealed that democratic South Africa has proved to be an extension of colonial and apartheid states by its use of undemocratic means such as the police, arrests and prisons to resolve its societal problems including the \#FeesMustFall campaign by university students in 2015 and 2016. The new South African state was not able 
to follow democratic principles such as engagement, negotiation, discussion, persuasion or participation with students and their parents to address the challenges they faced. The state confirms that it used coercive measures to enforce its authority. Police and prisons were used to deal with \#FeesMustFall campaign student leaders. According to the literature, students engaged in the \#FeesMustFall protests in order to decolonize the current state of education that the apartheid government established by creating separate universities. Universities were set up for blacks who had been living in reserves with limited resources but their administration remained under the management of whites. When the universities opened their doors for everyone after the fall of apartheid students still experienced the legacy of apartheid through the curriculum and the presence of statues such as those of Rhodes.

The literature has also reveals that university students lack general understanding of the impact of destroying the infrastructure such as setting university buildings on fire. They fail to understand that negotiation and engagement are keys in the new dispensation. However, this also reveals the failure of government to be pro-active in dealing with challenges in the country. The issue of free education is enshrined in the founding document of the Freedom Charter but after 24 years in power, the ruling party has failed to implement its provisions and the students have lost patience. South African universities still need to be "decolonized" by recognizing the contribution of all its citizens to the community and not just those of whites whose statues still stand guard on some university campuses. There is a lack of understanding of the link between the 1976 student revolt and the 2015 and 2016 university revolutions which have been sweeping the whole country since the time of Harold Macmillan's Wind of Change speech in 1960. This lack of understanding of the link between the two events is a clear indication of the failure of both political and university leadership. This study recommends that the state should be pro-active in understanding its mandate of promoting the welfare of society and students in particular by implementing the provisions of the constitution. Universities should decolonize the management and the philosophy of the institutions of higher learning in line with democratic principles. The state should develop new systems of government without resorting to the same institutions, namely the army, police and prisons that were used to suppress the indigenous people who were punished for resisting the brutal dispossession of their country. The state should look into possibilities of introducing free education for undergraduate degrees. Social grants for young mothers should be abolished as well as the provision of free housing and the funds thus saved should be used to finance sustainable programs such as free education. Strong leadership at both state and university level should be developed through training and development programs.

\section{Acknowledgement}

The author acknowledges Mr GT Owen for professionally editing this manuscript.

\section{References}

Adams, J. Khan, H.T.A., Raeside, R., \& White, D. (2007). Research Methods for Graduate Business and Social Science Students. London: Sage. 


\section{Macrothink}

Journal of Public Administration and Governance

ISSN 2161-7104

2016, Vol. 6, No. 4

African National Congress. (1997). Umrabulo: Draft Strategy and Tactics Document. Special ed. No.4. Department of Political Education and Training.

African National Congress. (1998). Ethical Transformation: ANC Statement on the Moral Renewal of the National: National Executive Committee.

Badenhorst, C. (2008). Dissertation writing: A Research journey. Hatfield: Van Schaik.

Buys, R. (2016, March 17). A student convention can avert revolution. The Sunday Times, p.17.

Cele, S. (2016, August 21). "Find the money". The City Press, p.1.

Cele, S., \& Stone, S. (2016, September 10). State of Crisis. The City Press, p.1.

Cheru, F. 2010. Overcoming apartheid's legacy: The ascendancy of neoliberalism in South Africa's anti-poverty strategy. Journal of Third World. Published online: http://dx.doi.org/10.1080/01436590120071768, p. 505-527.

Crowther, D., \& Lancaster, G. (2009). Research methods: A Concise introduction to research in management and business consultancy. $2^{\text {nd }}$ ed. London: Elsevier.

Davids, N., \& Mbele, G. (2015, October 21). Students take \#FeesMustFall protest to Parliament. Times Life.

Engels. F. 1884. Origin of the Family, Private property and the State. Hottingen-Zurich.

Evans, J. (2015, April 8). We have Rhodes's corpse, SA has his statue. Mugabe. News24.

Fanon, F. (1965). The Wretched of the Earth. London: Penguin Books.

Farroq, U. (2013). A Brief Note on Plato Ideal State Concept. www.study.

Goldstone, J. (2001). Towards a Fourth Generations of Revolutionary Theory. Annual Review of Political Science. 4, p139-187.

Gwala, N. in Cobbert, W. \& Cohen, R. (1988). Trenton: African World Press.

Havey, E. \& Fakir, S. (2016, October 21). Decolonise Science at your peril. The Mail and Guardian, p. 26.

Henning, E., van Rensburg, W., \& Smit, B. (2004). Finding your way in qualitative research. Hatfield: Van Schaik.

Hyslop, J. (in Cobbett \& Cohen, R. (Eds.). (1988). Popular Struggles in South Africa. New Jersey: Africa World Press, Inc. pp. 186-187.

Iwase, M. (2014). A Violent Protest for Education. From Soweto-uprising-n686g8.pdf

Klaus, H. Goetz, K.H. 2008. Governance as a Path to Government. Journal of West European Politics, Published online:_http://dx.doi.org/10.1080/01402380701835066.Vol. 31 (1-2), p. 258-279. 


\section{Macrothink}

Journal of Public Administration and Governance ISSN 2161-7104 2016, Vol. 6, No. 4

Kumar, R. (2014). Research Methodology: A step-by-step guide for beginners. $4^{\text {th }}$ ed. London: Sage Publications.

Lenin, V.I. (1019). The State and Revolution. The Marxist Theory of the State \& the Tasks of the Proletariat in the Revolution.

Macupe, B. (2016, September 22). Police use force to disperse march. The Sowetan, p.2.

Makhanya, M. (2016, August 28). Stop the war on knowledge. The City Press, p. 2.

Makhubu, N., Ndlazi, S., \& Gwangwa, V. (2016, September 2). Campuses close as student anger rages. Pretoria News, p.1.

Mitropolitski, S. (2011). Weber's Definition of the State as an Ethnographic Tool for Understanding the Contemporary Political Science State of the Discipline. Canadian Political Science Association, May 2011. University of Montreal.

Musitha, M.E. \& Tshibalo, L. (2016). The Politics of language in South African institutions of higher learning. Journal of Research in Social Science. 4 (6), 1-11.

Musitha, M.E. (2016). The Challenges of Name Change in South Africa: The Case of Makhado Town. Open Journal of Social Sciences, 4, 57-68. http://dx.doi.org/10.4236/jss.2016.42010.

Neitzel, L. (N.D). What is Revolution. Retrieved from www.columbia.edu/cu/weai/--revolutions/pdf/what -is-revolution.pdf.

Pambazuka News. (2016). The fall of Cecil John Rhodes and the rise of Black Power. Retrieved from http://www.pambazuka.org/printmail/91843.

Sargent, L.T. (2009). Contemporary political Ideologies: A Comparative Analysis. Belmont: Wadsworth.

Saro-Wiwa, K. (1995). A Month and a Day Diary and Letters. Banbury: Ayebia Clarke Publishers.

Schwarzmantel, J. (2010). Democracy and violence: a theoretical overview. Journal Democratisation, published online: http://dx.doi.org/10.1080/13510341003588641_17 (2), 217-234.

Stone, S., Mashego, A. \& Cele, S. (2016, October 2). State security says it will have zero tolerance. www.citypress.co.za. The City Press, p.1.

Tau, S. (2016, September 20). Students united in rejecting Nzimande's offer. The Citizen, p. 5.

Wikipedia, (2016). What is revolution. Free encyclopedia.

Wikipedia, (2016. Marx Theory of the State. Free encyclopedia. Retrieved from https://en.wikipedia.org/wiki/Marx's_theory_of_the_state 


\section{Macrothink}

\section{Copyright Disclaimer}

Copyright for this article is retained by the author(s), with first publication rights granted to the journal.

This is an open-access article distributed under the terms and conditions of the Creative Commons Attribution license (http://creativecommons.org/licenses/by/3.0/). 